\title{
The Engineering Design Competency
}

\author{
The NSERC Chairs in Design Engineering \\ Jorge Angeles (McGill University), Ron Britton (University of Manitoba), Liuchen Chang \\ (University of New Brunswick), François Charron (Université de Sherbrooke), Peter Gregson \\ (Dalhousie University), Peihua Gu (University of Calgary), Peter Lawrence (University of \\ British Columbia), Warren Stiver (University of Guelph), David Strong (Queen's University), \\ Paul Stuart (École Polytechnique), Brian Thompson (University of Western Ontario) \\ Email contact:paul.stuart@polymtl.ca
}

\begin{abstract}
There is increasing global competition for better product and process functionality, higher quality, lower costs, and other considerations including energy and environmental challenges. This trend requires that Canadian industry be more innovative and responsive in order to stay competitive internationally. The Canadian capability in Engineering Design is at the core of our ability to achieve this goal. At both the undergraduate and graduate levels, we must improve the capability and capacity of engineering graduates so that they are capable of leading innovation, and converting research results into value-added products and services. This paper addresses the engineering design competency, identifies needs in engineering design training, and describes directions for the design content in engineering education programs.
\end{abstract}

\section{Introduction}

In 1999, a new NSERC chair program was created in Design Engineering. The NSERC Design Chair Group has undertaken an initiative to develop a definition of the Engineering Design Competency from which universities may draw inspiration in the design of new and innovative engineering education programs.

In response to various factors including particularly a demand by the business and engineering communities for enhanced design competencies in graduating engineers, there is a trend in engineering accreditation towards "outcomes-based" assessments and the integrated engineering design curriculum. Under outcomes-based criteria, engineering programs must demonstrate that their graduates have an ability to apply knowledge of mathematics, sciences and engineering. This incorporates the evaluation of design competencies such as, for example, the ability to design and conduct experiments, and the ability to design a system, component, or process to meet desired needs.

Traditionally, quality in engineering education has been achieved by providing high quality instruction, excellent lab facilities, and relevant tutorials and assignments. However, the engineering design competency cannot easily be developed in the traditional classroom setting. Various approaches are currently being adopted by universities in engineering design education including innovative strategies for engineering design content within individual degrees, employing interdisciplinary approaches, and projectbased learning.

To further improve engineering design competency in graduates, a number of issues and challenges must be addressed which may touch the very foundation of university traditions. These include such factors as the current university reward systems, academic programs development and approval processes, traditional engineering education models, engineering accreditation requirements and processes, and the academic culture in Canadian engineering schools. New thinking towards engineering education as well as research and innovation are essential in order to evolve Canadian engineering education to a new model that will produce engineering graduates who are designready and confident in their ability to innovate.

This paper is an abbreviated version of a white paper entitled The Engineering Design Competency prepared by the NSERC Chairs in Design Engineering.

\section{Current Trends in Engineering Design Education}




\section{Accreditation}

To ensure that engineering programs offered by education institutions meet educational standards acceptable for professional engineer registration, and that the quality and relevance of engineering education continuously improve, engineering associations of many countries in the world have established accreditation mechanisms to evaluate and accredit the undergraduate engineering programs of education institutions. Accreditation is usually a voluntary, nongovernmental process of peer review. In Canada, the Canadian Engineering Accreditation Board (CEAB), a standing committee of the Canadian Council of Professional Engineers (CCPE), has been responsible for the accreditation of Canadian engineering education programs since 1965 .

In order be accredited, an engineering program must meet or exceed the accreditation criteria established and published by CEAB. Accredited engineering programs must contain not only adequate mathematics, sciences and engineering content, but also adequate complementary studies that deal with central issues, methodologies and thought processes of the humanities and social sciences. The programs must also allow students to develop communication skills and an understanding of the environmental, cultural, economic and social impacts of engineering on society and the concept of sustainable development (CEAB 2002).

Engineering education has been progressing in response to the technological advances, political and economic realities, engineering job markets and public interests. As a quality assurance program, engineering accreditation is also evolving. The following trends have been observed in engineering accreditation in recent years.

Outcomes Assessment: Many engineering accreditation organizations outside Canada have shifted away from prescribing what engineering programs should be like, and are evolving toward examining the outcomes of engineering education. The old criteria set standards for faculty size, curricular requirements, and the quality of laboratories and other facilities. The new criteria focus increasingly on the educational objectives of engineering programs, and evaluation procedures that track whether objectives are met. For example engineering graduates should have an ability to apply knowledge of mathematics, sciences and engineering, an ability to design and conduct experiments as well as to analyze and interpret data, an ability to design a system, component, or process to meet desired needs, and other similar outcomes (U.S. Accreditation Board for Engineering and Technology or ABET, 2001).
Engineering Design: Under outcomes based criteria, engineering design has been emphasized as a key component by accreditation organizations. CEAB specifies the minimum of 225 academic units for engineering design, and expects that Faculty teaching engineering science as well as engineering design to be registered professional engineers.

Internationalization: Globalization has been an important phenomenon in engineering professions, as marked by mobility of practicing engineers and students across the borders of countries. International agreements on engineering education, accreditation and practice have thus been developed. One of the first agreements was signed in 1980 by the CEAB and the Engineering Accreditation Commission (EAC) of the United States, where the two parties mutually recognize graduates of all engineering programs accredited by each party.

New and Innovative Engineering Programs: Rapid development in technology has led to formation of numerous new engineering disciplines. Accreditation organizations have responded to these needs of the engineering community by accrediting new programs. Examples that have been accredited during the past couple of decades include computer engineering, geomatic engineering, oil and gas engineering, software engineering and environmental engineering.

Partnerships in Education: Interactions and partnerships between engineering educational institutes and outside stakeholders such as engineering organizations and associations, and industry and businesses have been rapidly developed and strengthened in recent years. Partnerships in engineering education have been ongoing in two areas:

- providing engineering students with real-world practical experience as an integral part of their academic program, and

- inviting "outsiders" from engineering and business communities into the advisory and decisionmaking bodies controlling the engineering curriculum.

These activities triggered changes in curricula leading to the development of new means of delivery of engineering education, accelerated the emphasis in engineering design and project-based learning, and promoted the inclusion of "soft skills" such as communications and team work.

\section{Strategic Issues in Engineering and Engineering Design Education}


Tomorrow's engineers must cope with problems and challenges significantly different from their predecessors.

In the following points, some specific strategic decisions related to Engineering Education are discussed that must be addressed in the coming years.

\section{Program Structure by Discipline and Subject}

Canada's Innovation Strategy (Government of Canada 2002) points to the "need to encourage cross-training and a multidisciplinary approach, in order to build capacity among MBAs and engineers for the commercialization of these new technologies". The new technologies referred to were environmental and green energy, but the statement could equally apply to any innovative technology.

"The last half or more of the 20th century ... has found that the world of practical applications is increasingly crossdisciplinary, and even more rapidly becoming interdisciplinary. The integration across fields in the world of practical applications is often delayed until the engineer has moved into a job rather than being part of his or her university education. Universities should move to meet their obligations to students and to society need to move toward true interdisciplinarity" (Coates 2000).

The need for true interdisciplinarity programs is driven by increased local and global competitiveness, both because industry is rewarded for getting to market first (first-mover advantage) and because markets are no longer defined geographically. To meet this need, product realization has become a more concurrent and less linear process in most companies, requiring a large variety of skills on the part of the design team. In addition, the rate of employment and innovation is now greatest in small to medium sized enterprises. These organizations require employees to have considerable familiarity with all aspects of the design.

Canadian universities and engineering faculties must continue to identify these market trends and create interdisciplinary programs and training opportunities which respond to our evolving needs.

Engineering Curriculum Renewal with Technology Changes and Knowledge Growth

The short- and long-term needs of engineering students and employers are often in conflict. If engineering education is to make students maximally employable in the short term, it would risk delivering training for the latest CAD software or the use of a particular instrument or process, rather than emphasizing a sound understanding of the principles on which these tools are based. However, to ignore the latest technology, the latest software or the latest code/regulatory changes leads to graduates that are out of step with the practice of engineering.

The rapid pace of knowledge growth in engineering presents a motivation for increased specialization within engineering curricula. Curriculum renewal continues to be faced with adding content to reflect new fields and new technologies, however for every addition, some content must be removed.

\section{Continuity in Design Education}

Most Canadian engineering schools have a first year design course and a final year capstone design sequence including design project. In the first year course, students tackle a relatively simple problem with considerable assistance from teaching assistants and faculty members. The capstone design sequence is based on open-ended projects offered by industry and/or faculty members. Each group of students typically undertakes a different project with the result that the ability to learn from each other is minimized. In this model, students can become frustrated as their design skills have not progressed sufficiently to handle the degree of open-endedness of an industry project.

Alternatively, a number of engineering schools offer a "continuum of design" throughout the curriculum. Harvey Mudd College (Bright 1999) has been offering a sequence of design courses for approximately 40 years, and a number of Canadian engineering schools now offer a continuum of design courses (e.g., University of Guelph in all programs, University of Manitoba in Biosystems Engineering, University of Sherbrooke in several departments, and Electrical and Computer Engineering at Dalhousie University).

Providing a design continuum is critical, however requires significant cooperation between departments. The problems associated with ensuring extensive collaboration between faculty members with the requisite expertise are exacerbated by timetabling, resource allocation, space, and registration issues.

\section{Design Facilities}

Team-based design and design in general relies on a different mix of educational space than engineering science courses. Design studios, shop (machine or equivalent), storage space, advanced software, and large-format printers are just some of the unique needs. Design studios in particular are not commonly found in engineering schools in Canada, although some schools have developed them. In particular, the University of Western Ontario has developed studio-based design (Thompson, 2001), Queen's University has the Integrated Learning Centre (Integrated Learning Center, 2004), and the Mechanical Engineering Departments at Sherbrooke University and the 
University of Calgary have created considerable design facilities and spaces for undergraduate students.

\section{Faculty Renewal}

In Germany, 10 to 15 years of industry experience was the rule until recently (Altan, 2003). Some schools have implemented proactive programs to engage faculty and students with industry (Denton 2003) so as to make faculty more familiar with the modern manufacturing environment and to keep faculty technically current.

Approximately one-third of the Canadian university engineering faculty in tenured or tenure-track positions are over the age of 50 and thus retiring within the next 15 years (CCPE 2003). The significant faculty renewal that is now underway in Canada presents an opportunity for innovation and advancement in engineering education while at the same time presents some risks.

Tenure, promotion and compensation policies play a critical role in shaping the activities and priorities of all faculty, and are especially important for new faculty. An opportunity exists to reward interaction with industry, attract expertise from industry, and to restructure some courses to better reflect the teamwork, communication and collaboration skills that are needed by industry and society (EEIC 1997, Denton 1997, Bell 2000, Grinter 1955).

For example, engineering design teaching is recognized as requiring considerably more time for course development, project selection and student consultation. Course loads for team-taught engineering design courses must be computed appropriately so as to recognize the extra effort required for developing and delivering these courses.

The Macleans Magazine "Ranking Canadian Universities" (www.macleans.ca) has grown in influence and attention on many campuses. In faculty terms, measurement focuses on the percentage with $\mathrm{PhD}$ 's and funding from the major granting councils. Additional important measures for engineering might include such things as industrial experience, P.Eng status, and collaboration/funding relationships with industry.

\section{Back to Basics}

Engineering Design is iterative, creative, at times both analytic and synthetic, incorporates elements of problem-solving, and incorporates intuitive as well as heuristic methodologies. Design is decision-based and goal-directed; designers are presented with problems motivated by human need, related to products, processes, materials and systems of all kinds, and bring to bear rational tools and imagination in methodologies developing optimal solutions (Covo 2003).

The Canadian Engineering Accreditation Board has proposed the following definition of engineering design (CEAB 2002): Engineering design integrates mathematics, basic sciences, engineering sciences and complementary studies in developing elements, systems and processes to meet specific needs. It is a creative, iterative and often open-ended process subject to constraints that may be governed by standards or legislation to varying degrees depending on the discipline. These degrees may relate to economic, health, safety, environmental, social or other pertinent factors.

In its guide on the professional practice of engineering in Canada (CCPE 2001b), the Canadian Council of Professional Engineers defines the following characteristics of a profession:

A profession is a learned calling that requires advanced knowledge, understanding, and abilities gained from intensive and specialized education, training, and practical experience. Members of a profession limit their activities to their areas of knowledge and experience, doing so out of commitment to serve and protect the public. Professional practitioners also ensure that their competency is maintained throughout their careers.

In addition to theoretical and technical knowledge, effective professional practice requires reflective and practical knowledge and competencies for dealing with problems in the indeterminate zones of practice, that is, the areas that do not yield to technical or familiar solutions. These competencies are critically important to the education and development of professionals in the climate of rapid technological, cultural and economic change. A number of researchers in the field of professionalism and skills, such as Le Boterf (2002), share this broadened vision of the profession.

\section{The Engineering Design Competency}

\section{A Competent Design Engineer}

A review of the literature offers many descriptions of professional engineering competencies in general. But what does it say about the design engineer? Is there a definitive list of skills, personality traits, behavior, and a body of knowledge that sets design engineers apart from other engineering practitioners?

North American educators typically approach design as a subset of skills for all engineers. However based on industrial demand (Frise 2002), there are too few 
institutions that train engineers with explicit design competency.

Many engineering educators believe that students should understand how to generate design specifications and how to proceed from design specifications to a final artifact by establishing objectives and criteria, generating alternatives, synthesizing, analyzing, constructing, testing, and evaluating (Sheppard 1999).

\section{Established Skills for Design Engineers}

This review examines the skills that set design engineers apart from other engineering practitioners. Technical Skills

There is little apparent concern over the level of competency amongst design engineers in math, basic sciences and engineering sciences (Eggert 2002, Frise 2003, CCPE 2001a), although graduates have trouble applying those skills to proper technical design analysis (Dempster 2001).

Experience and "Know-how"

Above all other skill-level considerations, design engineers require some level of hands-on competency in the use of tools or processes relevant to their field (Frise 2002, Bell 2000, Eggert 2002, Frise 2003, Hubka 1992, Evatt 2001, CCPE 2001a). These skills are lacking among North American engineering graduates, based on the frequency with which this issue appears in the literature.

Where design engineering skills have been identified as separate from typical engineering science, there is a recurring principle of learning-by-doing (Hubka 1992). Experiential competency is defined as an innate ability and as a "set of instincts about the likely consequences of certain choices which every professional faces every day" (Frise 2003).

\section{Specific Design Activities}

Industry and academe cite a wide range of preferences in formal design methodologies. While each industry segment has its particular methods, design engineers should able to implement the following:

- Methods and rules for the larger design process including Design for X (Frise 2002, Eggert 2002, Bajaj 2002, Oakley 1990, Boothroyd 1994, Boothroyd 2001, Fu 2000, Gattiker 2003), identification of constraints and needs such as QFD (Eggert 2002, Radcliffe 1994), quality control processes such as Six Sigma or TQM (Frise 2002, Eggert 2002), and use of project management structures (Frise 2002, McCowan 2002, Eggert 2002, Boothroyd 2001, Dekker 1996, Asbjornsen 2000, Evbuomwan 1996);
- Rules for design analysis and design improvement such as Failure Mode Effect Analysis, product testing, process integration, etc. (Eggert 2002, Boothroyd 1994, Zhang 1998, Lewin 2003);

- Methods for creativity such as brainstorming to TRIZ (Frise 2002, Eggert 2002, Dieter 2000, Ertas 1996, TRIZ 2004);

- Specific technical skills with special emphasis in design, for example solid modeling techniques (Frise 2002), computer-aided process engineering (CAPE) (Peters 2003), computer assisted design (CAD) (Davis 1996, Eggert 2002, Evatt 2001, Sorby 2000, Lewin 2003), geometric dimensioning and tolerancing (GD\&T) (Frise 2002, Eggert 2002) and computational fluid dynamics (CFD) (Kundu 2000, Birtigh 2000);

- Other design knowledge including safety methodologies (McCowan 2002, Eggert 2002, Hales 2003, Guzman 2003, Kelly 2004), regulatory issues (Eggert 2002) and human factors (Eggert 2002, Tolf 2003).

\section{Attitudes Toward Design Engineering}

Professional attitude is widely cited as a key competency for engineers in general along with the ability to adapt to changes in circumstances (Frise 2002, Wisler 2003). Design engineering practice suffers from varying attitudinal pathologies. "NotInvented-Here" attitudes (Wisler 2003), confusion of originality with creativity (Thomas 2000), notions of design as an individual activity (Thomas 2000), and unwillingness to leverage the knowledge of technicians or tradesmen (Eggert 2002) are recurring problems amongst new graduates of university engineering programs.

\section{Business Skills}

Recent literature suggests novice engineers require at least an introductory familiarity with business issues. These skills are identified as pertinent to all engineers, and not just design engineers. Important business issues for engineers (in general) include project management skills (Eggert 2002, Lauche 2003, CCPE 2001a, Lahidji 2000), customer awareness (Santiago 2001), knowledge of basic issues in business finance including cost of money, corporate ownership structures and liabilities (McCowan 2002, Eggert 2002, Wisler 2003, CCPE 2001a), basic economic principles (Lahidji 2000), risk analysis and budgeting (Frise 2002), social skills applicable to a multicultural business environment (Wisler 2003, Lahidji 2000), understanding of corporate culture and the global nature of business (Frise 2002, Wisler 2003, Dempster 2001, Sekiguchi 2001), and appreciation for intellectual property (Wisler 2003). 


\section{Communications Skills}

Employers expect young engineers to able to draft comprehensible, compelling reports (Eggert 2002), express themselves verbally (Frise 2002, Davis 1996, Eggert 2002), listen effectively, and be able to "sell" concepts, products and themselves to the technically savvy as well as to laypeople (Davis 1996).

Teamwork Skills

Every comprehensive list of engineering competencies includes the ability to work effectively in teams. Typically, teamwork skills receive highest priority among the design engineering competency (Frise 2002, Eggert 2002). Yet, despite the importance of teamwork and other social skills, they are not assessed systematically in the process of educating design engineers (Lauche 2003, Cowdroy 2002).

Lauche (2003) has surveyed several important communications and project management skills for the design process including negotiation with clients, problem solving, acceptance of responsibility, interpersonal skills, planning, exchanging information, coordinating activities, assessing capabilities of others, workload management, team building and collaboration.

\section{Incorporating the Engineering Design Competency in the Curricula of All Engineering Disciplines}

This section provides perspectives on design competency as they relate to the broad context of the practice of engineering. Table 1 provides a definition of the engineering design competency as applicable to all disciplines. It is not expected that a single graduate or an engineering program would be competent in all of the listed items. Only 2 of the Engineering Competencies in Table 1 are treated in this paper, however more details can be found in the complete Design Competency Document by the NSERC Chairs in Design Engineering (2004).

\section{Specific Knowledge in a Professional Environment}

In the words of the Canadian Council of Professional Engineers (CCPE 1997): Canadian engineers provide leadership to advance the quality of life through the creative, responsible and progressive application of engineering principles in the global context.

"Quality of life" is a broad term that recognizes the importance of economics, social and environmental domains that are all essential for realizing a high standard of living. These domains are the pillars of sustainable development (World Commission on
Environment and Development, 1987). CEAB accreditation guidelines reinforce that knowledge of the principles of sustainable development is essential for all engineers (CEAB 2002).

Safety: The practice of engineering is fundamentally about the protection of public safety. As designers, graduating engineers should be exposed to and have some experience with one or more of the classical techniques to identify and reduce safety risks. HAZOP, FMEA, and FTA are three common techniques.

Ethics: Morrison and Hughes (2003) is a leading reference on ethical aspects for Canadian Engineering practice.

Codes, Laws and Regulations: Codes, laws and regulations influence all engineering design. For example Workplace Hazardous Materials Information System (WHMIS), established in 1987, has become fully integrated into the Canadian workplace. All graduating engineers should be knowledgeable of WHMIS and its impact on their designs (WHMIS 2004).

Standards: Standards are critical to many aspects of our lives, although this is not obvious to most. When possible, Design Engineers should rely on standard components to design and build complex systems. They should know where to look to find standard specifications for a bolt or a pipe, and should customize only when necessary. Engineers should be aware of which standards are applicable to their work, and aware of testing and certification processes. The success and the growth of the ISO 9000 series in quality management and the ISO 14000 series in environmental management means student exposure to these standards is important within the engineering curriculum.

Intellectual Property: Many design engineers will create new intellectual property (IP) over the course of their career, and will use existing intellectual property in the development of solutions. Engineering graduates should be aware of the various forms of intellectual property (patents, trademarks, copyright, and industrial designs). Most universities have an Intellectual Property office that can be an important resource in support of the curriculum.

Technologies: All graduating engineers must have awareness and some technical understanding of a broad range of technologies beyond the technologies of their engineering discipline. This breadth of awareness is necessary to support the development of creative solutions, understanding engineering systems and components, working in cross-disciplinary teams and ultimately leading larger engineering projects. 
Table 1. Proposed definition of the design engineering competency

\begin{tabular}{|c|c|c|}
\hline Type & Description & Engineering - All disciplines \\
\hline \multirow{3}{*}{$\begin{array}{l}\text { General } \\
\text { knowledge }\end{array}$} & \multirow{3}{*}{$\begin{array}{c}\text { To understand a } \\
\text { phenomenon, a } \\
\text { situation, a } \\
\text { problem, a process, } \\
\text { etc. }\end{array}$} & $\begin{array}{c}\text { Linear algebra, Calculus, Differential Equations, } \\
\text { Probability, Statistics, Numerical Methods, Partial } \\
\text { Differential Equations, etc. }\end{array}$ \\
\hline & & Chemistry, Physics, Biology, Earth Science, etc. \\
\hline & & $\begin{array}{c}\text { Mechanics, Materials, Fluid Mechanics, Circuits, } \\
\text { Thermodynamics, Heat Transfer, Mass Transfer, } \\
\text { System Control, etc. }\end{array}$ \\
\hline $\begin{array}{c}\text { Specific } \\
\text { knowledge in a } \\
\text { professional } \\
\text { environment }\end{array}$ & $\begin{array}{l}\text { To know the } \\
\text { technologies, the } \\
\text { rules, the standards, } \\
\text { the culture, etc. }\end{array}$ & $\begin{array}{c}\text { Technologies, standards, regulations, safety, liability, intellectual } \\
\text { property, ethic, role in the society }\end{array}$ \\
\hline $\begin{array}{l}\text { Knowledge of } \\
\text { procedures }\end{array}$ & $\begin{array}{l}\text { To know the } \\
\text { procedures, the } \\
\text { methods, the } \\
\text { processes, etc. }\end{array}$ & $\begin{array}{l}\text { Product development process, engineering design process, engineering } \\
\text { design tools (market research, functional analysis, QFD, design for cost } \\
\text { and cost estimation, etc.) }\end{array}$ \\
\hline $\begin{array}{l}\text { Operational } \\
\text { skills }\end{array}$ & $\begin{array}{c}\text { To know how to use } \\
\text { methods, } \\
\text { procedures, } \\
\text { technologies, etc. }\end{array}$ & To have executed and practiced the design process \\
\hline $\begin{array}{l}\text { Experiential } \\
\text { skills }\end{array}$ & $\begin{array}{l}\text { To know how to use } \\
\text { tacit knowledge }\end{array}$ & Design by similarity, design by experience, etc. \\
\hline \multirow{3}{*}{$\begin{array}{l}\text { Social/ } \\
\text { Personal skills }\end{array}$} & $\begin{array}{l}\text { To know how to } \\
\text { listen, to cooperate, } \\
\text { to work in team, } \\
\text { etc. }\end{array}$ & Teamwork, communications, leadership, negotiation, professionalism \\
\hline & $\begin{array}{l}\text { Initiative, thorough, } \\
\text { curious, etc. }\end{array}$ & $\begin{array}{l}\text { Initiative, thorough, curious, practical, humble, responsible, adaptable, } \\
\text { confident, awareness, respectable, entrepreneurialism }\end{array}$ \\
\hline & $\begin{array}{l}\text { To manage life } \\
\text { (personal and } \\
\text { professional), } \\
\text { To feel (intuition, } \\
\text { perception, etc.) }\end{array}$ & $\begin{array}{l}\text { Self-awareness, managing emotions, motivating oneself, empathy and } \\
\text { handling relationships }\end{array}$ \\
\hline Cognitive skills & $\begin{array}{l}\text { To solve problem, } \\
\text { to design, to manage } \\
\text { a project, to take } \\
\text { decisions, etc. }\end{array}$ & $\begin{array}{l}\text { To know your limitations, to create, to look at the big picture, to manage } \\
\text { projects (including the system engineering perspective), to decide } \\
\text { (decision-making), to learn how to learn, to manage information and } \\
\text { knowledge, to define a problem, to define potential solutions, to learn } \\
\text { from past experiences, to manage resources, to take and manage risk }\end{array}$ \\
\hline
\end{tabular}




\section{Knowledge of Procedures}

Knowledge of the design process and an awareness of the various design tools are the starting points for a design competent engineer.

\section{Design Process}

Knowledge of the design process should encompass how the transition is made from an idea, a vision or a problem through to the technical specifications of the product, process, or solution. Final implementation of the solution is the conclusive step in the design process. The Design Process is described in varying detail through numerous references including Dieter 2004, Voland 2004, Ullman 1997, and Ertas 1996.

Engineers should be well versed in the terminology associated with the design process. Conceptual design, feasibility study, preliminary design, final design, detailed design, concurrent design and embodiment design are all terms used to describe portions of the design process.

Additional knowledge includes where R\&D, testing, prototypes and pilot scale activities fit into the process. Knowledge encompasses recognition that the process is usually iterative.

\section{Design tools}

Design tools to support the design process come in many forms depending on the stage of the process and on the nature of the design problem. The tools include people as sources for problem definition and data gathering. Libraries (as a title encompassing all information sources) are primary tools in the early information gathering stage. Knowledge of this tool must include awareness of the various types of sources (textbooks, journal literature, patents, gray literature, the web, standards, codes, regulations, and people) and the recognition that all sources are important.

Engineering drawings are essential tools for the process. Sketches, generated by pencil and paper, are the most frequent start to the process. Sophisticated Computer-Aided Drawing software has become integral to the process as a design matures. Knowledge means that the engineer is aware of the role of both ends of this spectrum.

Engineering calculations are key tools in the design process. Back of the envelope approximations will parallel the sketch drawing stage. Sophisticated Computer-Aided Engineering software, capturing the 3D and transient complexity of a system, are increasingly playing a role in preliminary and detailed design work. Again, knowledge means that the engineer is aware of the existence and capabilities of these tools.
Performance Assessment against Criteria and Constraints

Problem definition usually identifies appropriate constraints (the musts) and desired criteria (the wishes). The constraints must each be achieved. The criteria are dealt with in a collective balancing act. Quantifying each of the identified factors eases the subsequent decision making stage.

Cost is always a factor in engineering design and cost estimation has become an important field on its own. Cost estimation is necessary at various stages of the design process. Cost estimating relies on experience and thus depends on empirical relations. The chemical engineering field has well developed empirical relations to support cost estimating (Peters 2003). SAE provides a structured format for cost estimating for the student Formula SAE competition (Bowman 2000). This format could be effectively used within engineering curriculum.

Environmental performance is another important factor. Life cycle analysis is a growing capability and should be an element of all engineer's knowledge base.

The literature on engineering design and the practice of engineering design has introduced the use the terms: "Design for Cost", "Design for Reliability", "Design for the Environment", and others (Poli 2001, Dhillon 1999, Corbett 1991, Rouse 1991, USEPA 2004, NRC 2004a). These collectively are increasingly referred to as "Design for X" (see DFX terminology by Migliore 2004). The introduction of these concepts represents an effort to focus design attention on one particular criterion. They imply that design attention for " $X$ " has been lacking. The aspect that so many "X's" have been used reflects the design challenge of simultaneously optimizing numerous criteria.

\section{Decision making}

Decisions are an integral part of the design process. Many formal decisions and many more informal ones are made throughout the process.

Formal decisions are often at the conclusion of conceptual, preliminary and final design stages as part of recommending the next step and seeking budgetary approval to proceed to the next stage. Procedures have been developed to formalize this decision making process as part of fostering objectivity. Objectivity is important in all settings but it is particularly important in the public sector. The decision-matrix method is one common formalized approach that is a relatively simple to execute (Ullman 1997). However, it is important for students and engineers to recognize that subjectivity quickly becomes a part of the decisionmatrix approach through selection of criteria weightings and scoring rules. 
Informal decisions are made nearly continuously in the design process. Everything from assumptions made in a detailed calculation to what options to pursue following a brainstorming exercise. The challenge is to make these choices consciously and as objectively as possible with getting bogged down in "too much analysis leads to paralysis".

Decision making by consensus is an important skill to be developed by effective teams. "It takes time, energy and skill to reach consensus but consensus decisions have a greater likelihood of being implemented by the team" (Levi 2001).

\section{Conclusions}

The essence of profession engineering is captured in the definition of design competency. This definition is complex and profound, yet also a living entity that evolves alongside professional practice.

Design competency can provide the necessary foundation for ongoing renewal of the undergraduate curriculum in engineering. To implement design competency in current and future engineering programs, a number of issues and challenges must be addressed which may touch the very foundation of university traditions and operations.

New thinking towards engineering education, the academic system, and research and innovation may be needed to effectively evolve Canadian engineering education to a new model that will produce engineering graduates who are design-ready innovators and lifelong continuous learners with the required engineering competency.

\section{References}

ABET (2001), Criteria for Accrediting Engineering Programs, Effective for Evaluations During the 2002-2003 Accreditation Cycle, Accreditation Board for Engineering and Technology.

Altan, T. (2003), Mechanical Engineering education and Research in US and German Universities, Workshop of the German Science Council, Cologne, Germany.

Asbornjen, O. A., Hamann, R. J. (2000), Toward a Unified Systems Engineering Education, IEEE Transactions on Systems, Man and Cybernetics Part C: Applications-and-Reviews, 30(2):175-182.

Bajaj, A. et al. (2002), Estimating for Design Costs, AACEInternational.-Transactions-of-the-Annual-Meeting. pp. EST081EST086.

Bell T.E. (2000), Proven Skills: The New Yardstick for Schools, IEEE Spectrum, 37(9).

Birtigh A., et al. (2000), C.Y. 2000 CFD in chemical engineering from an industrial standpoint, Chemie Ingenieur Technik, 72:175 193. (in German)
Boothroyd, G. et al. (1994), Product Design for Manufacture and Assembly, Marcel Dekker.

Boothroyd, G. (2001), Why DFM ?, Design Engineering, September 2001, pp.15-16.

Bowman B.A., Farr J.V. (2000), Embedding Leadership in Civil Engineering Education, Journal of Professional Issues in Engineering Education and Practice - Proceedings of the ASCE, 126:16-20.

Bright A., Phillips J.R. (1999), The Harvey Mudd Engineering Clinic Past, Present and Future, Journal of Engineering Education, April 1999, pp. 189-194

CCPE (1997), A Vision for the Engineering Profession in Canada, Canadian Council of Professional Engineers, www.ccpe.ca.

CCPE (2001a), 2000 Engineering Work in Canada, Sectoral Focus Groups Synthesis Report, Canadian Council of Professional Engineers, pp. 11-12

CCPE (2001b), Guideline on the Professional Engineering Practice in Canada, Canadian Council of Professional Engineers, $17 \mathrm{p}$.

CCPE (2003), Canadian Engineers for Tomorrow: Trends in Engineering Enrolment and Degrees Awarded, www.ccpe.ca.

CEAB (2002), Accreditation Criteria and Procedures 2002, Canadian Engineering Accreditation Board.

Coates J.F. (2000), Innovation in the Future of Engineering Design, Technological Forecasting and Social Change, 64:121-132.

Corbett J. (1991), Design for manufacture : strategies, principles and techniques, Addison-Wesley, $357 \mathrm{p}$.

Covo, D. (2003), Personal Communication, School of Architecture, McGill University, Montreal.

Cowdroy, R., Williams A. (2002), Assessing Design Activity: Issues and Actions, Seventh International Design Conference, Dubrovnik, pp. 43-48.

Davis, D.C. and al (1996), Competency-Based Engineering Design Projects, 1996 ASEE Annual Conference.

Dekker, D. L. (1996), Difference Between Open-Ended Projects and Design Projects, Technology Based Re-Engineering Engineering Education, Proceedings Frontiers in Education Conference. Vol. 3, IEEE, Piscataway, N.J., pp. 1257-1259

Dempster, W.M. et al. (2001), Filling the gap; Engineering Design Analysis Within a Mechanical Engineering Curriculum, International Conference on Engineering Design - ICED '01, Glasgow, Aug. 2123, 2001.

Denton, H.G. (1997), Multidisciplinary team-based project work: planning factors, Design Studies, 18:155-170.

Denton, N.L., Hutzel W.J. (2003), Venturing Into Engagement, 2003 CIEC Conference, Tucson, Arizona, Jan 28-31, 2003, pp. 12-15

Dhillon, B.S. (1999), Design reliability: fundamentals and applications, CRC Press, 396 p.

Dieter, G.E. (2000), Engineering Design, 3rd Edition, McGraw-Hill, 798p.

EEIC (1997), Best Practices Summary Report, Workshop on Building Effective Industry/Academe Partnerships for Engineering Education Innovation, Engineering Education Innovators Conference, April 7-8 1997, Arlington VA.

Eggert, R.J. (2002), Response tables from industry members of ASME's Design Engineering Division and the Manufacturing Engineering Division - Engineering Design Education: Surveys of Demand and Supply, Boise State University, 2002.

Ertas A., Jones J.C. (1996) The Engineering Design Process, 2nd Edition, Wiley, 614p.

Evatt, M.A.C. (2001), Industrial Training - More than Just Work Experience?, International Conference on Engineering Design ICED '01, Glasgow, Aug. 21-23, 2001. 
Evbuomwan N. et al. (1996), Survey of Design Philosophies, Models, Methods and Systems, Proceedings of the Institution of Mechanical Engineers, Part-B: Journal of Engineering Manufacture. 210(B4):301-320.

Frise, P.R. et al. (2002), Mechanical Engineering Skills Needs in Canadian Industry, Annual Conference of the Canadian Society of Mechanical Engineers, Kingston, Ontario, 2002.

Frise, P.R. et al. (2003), Identifying the Design Body of Knowledge, International Conference on Engineering Design - ICED '03, Stockholm, Aug. 19-21, 2003.

Fu Y. et al. (2000) Process design for the environment: A multiobjective framework under uncertainty, Clean Products and Processes, 2:92-107.

Gattiker T.F. (2003), A Hands-on Application for Teaching Design for the Environment (DfE) Principles, Quality Management Journal, 10(4): 32-39.

Government of Canada (2002), National Summit on Innovation and Learning : Summary, Ottawa, 151p., www.innovationstrategy.gc.ca. Grinter L.E, (1955), Summary of the Report on Evaluation of Engineering Education, Journal of Engineering Education, September 1955, pp. 25-60

Guzman B., Vudgdelija J., (2003), Operations \& maintenance When "wait and see" isn't good enough: Applying HAZOP at Genelba - Adapting 'hazards and operability' techniques to power plant operation, Modern Power Systems, October, pp.33-37.

Hales, Crispin (2003), Respect Design or Expect Disaster !, International Conference on Engineering Design - ICED '03, Stockholm, Aug. 19-21, 2003.

Hubka, V., Eder, W.E. (1992), Design Science (translation of Einführung in die Konstruktionswissenschaft), Springer-Verlag, Berlin, Heidelberg, 1992.

Integrated Learning Centre at Queen's University (2004), appsci.queensu.ca/ilc/

Kelly G. (2004), Reducing risk and all that HAZ, Safety and Health Practitioner, 22(3):26-31.

Kundu A.K., Raghunathan S. (2000), A Proposition in Design Education with a Potential in Commercial Venture in Small Aircraft Manufacture, Aircraft Design, 3:261-273.

Lahidji, B. (2000), Competencies in Manufacturing Engineering Technology Programs from Employer's Point of View, Proceedings of the 33rd Annual NAIT Conference.

Lauche, K. (2003), Non-Technical Skills Training for Designers, International Conference on Engineering Design - ICED '03, Stockholm, Aug. 19-21, 2003.

Le Boterf, G. (2002), Développer la compétence des professionnelles - Construire les parcours de professionnalisation, $4 \mathrm{e}$ édition, Éditions d'Organisation, 312p.

Levi D. (2001), Group Dynamics for Teams, Sage Publishers Inc., $362 \mathrm{p}$.

Lewin, D.R. et al. (2002), Integrated process design instruction, Computers and Chemical Engineering, 26:295-306.

McCowan, J. D. and Knapper C.K. (2002), An Integrated and Comprehensive Approach to Engineering Curricula, Part One: Objectives and General Approach, International Journal of Engineering Education, 18(6):633-637.

Migliore H. (2004), Design for X, www.cecs.pdx.edu/ herm/capstone/mee9899/design/dfx/dfxterms.ht $\mathrm{m}$

Morrison C. and Hughes P. (2003), Professional Engineering Practice: Ethical Aspects, 3rd Edition, McGraw-Hill, 189p. NRC (2004a), Canadian Codes Centre, http://irc.nrccnrc.gc.ca/codes/home_E.shtml.
NRC (2004b), Design for the Environment, http://dfe-sce.nrccnrc.gc.ca/home_e.html

NSERC Design Engineering Group (2004), Engineering Design Competency, version 2 of white paper dated 24 May 2004

Oakley, M., editor (1990), Design Management: A Handbook of Issues and Methods, Blackwell Reference.

Peters, M.S., Timmerhaus, K.D., West, R.E. (2003), Plant Design and Economics for Chemical Engineers, 5th Edition, McGraw-Hill

Poli C., (2001), Design for manufacturing : a structured approach, Butterworth-Heinemann, 375p.

Radcliffe, D. F., Harrison, P. (1994), Transforming Design Practice in a Small Manufacturing Enterprise, Sixth International Conference on Design Theory and Methodology, American Society of Mechanical Engineers, Design Engineer, 68:91-98.

Rouse W. (1991), Design for success: a human-centered approach to designing successful products and systems, Wiley, $287 \mathrm{p}$.

Santiago, C. (2001), The Model Engineer for GE, Proceedings of the Conference on European Society for Engineering Education, Copenhagen.

Sekiguchi, S. et al. (2001), Design Skills and Education of New Employees, International Conference on Engineering Design - ICED '01, Glasgow, Aug. 21-23, 2001.

Sheppard, S. D. (1999), Design as Cornerstone and Capstone, Mechanical Engineering Design, Supplement - Mechanical Engineering, November 1999.

Sorby S.A. et al. (2000), Modernization of the Mechanical Engineering Curriculum and Guidelines for Computer-Aided Engineering Instruction, Comput. Appl. Eng. Educ., 7:252-260.

Thomas, C., Ame, E. (2000), Cultivating Design Competence: Online Support for Beginning Design Studio, Automation in Construction 9:83-91.

Thompson, B. E. (2001), Studio Pedagogy for Engineering Design, Int. Journal of Engineering Education, 18(1).

Tolf, Y. et al. (2003c), Human-Centred Engineers - A Model for Holistic Interdisciplinary Communication and Professional Practice, International Journal of Industrial Ergonomics, March 1, 2003, 31(3):195-202.

TRIZ (2004), Theory of Inventive Problem Solving Journal, www.triz-journal.com.

Ullman D.G. (1997), The Mechanical Design Process, 2nd Edition, McGraw-Hill, 340p.

USEPA (2004), US Environmental Protection Agency, Design for the Environment, http://www.epa.gov/dfe/index.htm

Voland G. (2004), Engineering by Design, 2nd Edition, Pearson Prentice Hall, 610p.

WHMIS (2004), www.hc-sc.gc.ca/hecs-sesc/whmis/index.htm

Wisler, D. C. (2003), Engineering — What You Don't Necessarily Learn in School, Mechanical Engineering Design, Supplemen of Mechanical Engineering, August 2003.

World Commission on Environment and Development (1987), Our Common Future, Oxford University Press, 400p.

Zhang, G. (1998), Information-Based Engineering Design and the ABET 2000, Proceedings of the 1998 28th Annual Frontiers in Education Conference, FIE. Part 2. Tempe, Arizona. 